\title{
PENGARUH LAMA PERENDAMAN DAGING SAPI DALAM BLEND JAHE (Zingiber officinalle Roscoe) TERHADAP pH dan KEEMPUKAN
}

\author{
The Effect of Soaking Time of Beef Meat in Ginger Blend (Zingiber officinale Roscoe) on pH and \\ Tenderness
}

\author{
Suratno, Ali Husni, Rr Riyanti and Dian Septinova
}

Department of Animal Husbandry, Faculty of Agriculture, University of Lampung

Jl. Prof. Dr. Soemantri Brojonegoro No.1 Gedong Meneng Bandar Lampung 35145

e-mail : sentrosol@gmail.com

\begin{abstract}
This study aimed to determine the effect of soaking time for beef meat in ginger blend (Zingiber officinale Roscoe) on $\mathrm{pH}$ and tenderness. This research was conducted at the Animal Production and Reproduction Laboratory, Department of Animal Husbandry, Faculty of Agriculture, University of Lampung. Meat samples were obtained from Z-Beef slaugher house at Bandarlampung. The study used an experimental method in a completely randomized design with four treatments and five replications using a $15 \%$ ginger blend solution. The treatments were beef meat without soaking, soaking for 10 minutes, 20 minutes and 30 minutes with ginger blend. The results obtained were analyzed with Analysis of Variance (ANOVA) at 5\% significance level and continued with the Least Significant Difference test (LSD test). The results showed that the soaking time with ginger blend had no significant effect $(\mathrm{P}>0.005)$ on the $\mathrm{pH}$ value, but it had a significant effect $(\mathrm{P}<0.005)$ on the tenderness of beef meat with soaking time was up to 30 minutes.
\end{abstract}

Key words: Beef, Ginger, Soaking time, $\mathrm{pH}$, and tenderness

\begin{abstract}
ABSTRAK
Penelitian ini bertujuan untuk mengetahui pengaruh lama perendaman daging sapi dalam blend jahe (Zingiber officinale Roscoe) terhadap $\mathrm{pH}$ dan keempukan daging. Penelitian ini dilaksanakan di Laboratorium Produksi dan Reproduksi Ternak, Jurusan Peternakan Fakultas Pertanian, Universitas Lampung. Sampel daging diperoleh dari RPH Z-Beef Bandar Lampung. Penelitian menggunakan metode eksperimental dalam rancangan acak lengkap (RAL) dengan empat perlakuan dan lima ulangan menggunakan larutan blend jahe $15 \%$. Perlakuan tersebut yaitu daging sapi tanpa perendaman blend jahe, lama perendaman 10 menit, 20 menit dan 30 menit. Data hasil penelitian yang diperoleh dianalisis dengan Analysis of Variance (ANOVA) pada taraf nyata 5\% dan dilanjutkan dengan uji Beda Nyata Terkecil (BNT). Hasil penelitian menunjukkan bahwa lama perendaman blend jahe berpengaruh tidak nyata $(\mathrm{P}>0,005)$ terhadap nilai $\mathrm{pH}$, namun berpengaruh nyata $(\mathrm{P}<0,005)$ terhadap keempukan daging dengan lama perendaman hingga 30 menit.
\end{abstract}

Kata Kunci : Jahe, daging sapi, pH, keempukan.

\section{PENDAHULUAN}

Daging sapi memiliki banyak kelebihan, di antaranya mengandung vitamin B6 dan vitamin B12. Vitamin B12 hanya ditemukan dalam produk ternak dan sangat diperlukan untuk menjalankan metabolisme sel, menjaga sistem saraf agar tetap sehat, dan berperan dalam memproduksi sel darah merah. Selain itu, daging sapi mengandung zat besi, selenium, dan fosfor. Kandungan asam amino leusin, lisin, dan valin pada daging sapi lebih tinggi daripada daging babi maupun domba (Nusa Bali 2018).
Kualitas fisik bahan pangan termasuk daging menentukan kualitas produk olahannya. Perlakuan terhadap ternak sebelum pemotongan dan setelah pemotongan menentukan kuakitas fisik daging. Perlakuan sebelum pemotongan tersebut antara lain memberikan kesempatan pada ternak beristirahat selama sekitar 24 jam sebelum pemotongan. Hal tersebut bertujuan untuk mencegah ternak dari kejadian stres (mengalami cekaman). Menurut Aberle et al. (2001), daging ternak yang tidak diistirahatkan sebelum dipotong berwarna gelap, bertekstur keras, kering, nilai $\mathrm{pH}$ tinggi, dan daya mengikat 
air tinggi. Perlakuan pelayuan terhadap karkas hasil pemotongan ternak berpengaruh terhadap keempukan daging, flavor, dan daya mengikat air.

Daging bagian paha merupakan salah satu bagian hasil pemotongan sapi yang disukai konsumen. Permasalahannya, tekstur daging bagian paha alot karena merupakan bagian tubuh yang lebih banyak bergerak, antara lain untuk berjalan. Hal tersebut pada umumnya diatasi oleh konsumen dengan merebus daging terlebih dahulu sebelum diolah lebih lanjut. Kelemahan dari perlakuan tersebut adalah kerusakan beberapa jenis nutrisi . Upaya untuk memperoleh daging sapi bagian paha yang empuk dan kandungan nutrisinya tetap baik dapat ditempuh melalui proses perendaman daging dalam larutan jahe atau blend jahe. Jahe (Zingiber officinale) merupakan salah satu bumbu masakan yang banyak digunakan untuk meningkatkan rasa enak pada produk olahan.

\section{MATERI DAN METODE}

\section{Waktu dan Tempat}

Penelitian dilakukan pada 2 Mei 2019 di Laboratorium Produksi dan Reproduksi Ternak, Jurusan Peternakan, Fakultas Pertanian, Universitas Lampung.

\section{Materi}

Penelitian ini menggunakan $2,5 \mathrm{~kg}$ potongan daging sapi jantan bagian paha belakang (round) sebanyak 2,5 kg. Daging sapi diperoleh dari sapi yang dipotong di rumah potong hewan (RPH) Zbeef . Lokasi RPH tersebut di Kemiling, Bandarlampung.

\section{Metode \\ Rancangan percobaan}

Penelitian ini menggunakan RAL sebagai rancangan percobaan dengan empat macam perlakuan dan lima kali ulangan. Keempat perlakuan tersebut adalah daging sapi tanpa direndam dalam blend jahe (P0), daging sapi direndam dalam blend jahe selama 10 menit (P1), daging sapi direndam dalam blend jahe selama 20 menit (P2), dan daging sapi direndam dalam blend jahe selama 30 menit (P3).

\section{Analisis Data}

Data yang diperoleh dianalisis dengan analisis of varian (ANOVA) pada taraf nyata $5 \%$, apabila dari hasil analisis menunjukkan hasil yang nyata, maka dilanjutkan dengan uji BNT (Beda Nyata Terkecil).

\section{Pelaksanaan Penelitian}

Blend jahe dibuat dengan cara membersihkan kotoran yang terdapat pada kulit jahe, menghaluskan rimpang jahe menggunakan blender (Apriyanto et al., 1989). Jahe yang sudah bersih dipotong-potong dalam ukuran kecil agar mudah pada saat dihaluskan dalam blender. Selanjutnya dilakukan pembuatan jahe blend dengan cara sebagai berikut: $405 \mathrm{~g}$ jahe ditambah air lalu dihaluskan menggunakan blender. Air ditambahkan dalam larutan jahe sampai mencapai bobot total $2.700 \mathrm{~g}$. Bobot $2.700 \mathrm{~g}$ tersebut merupakan bobot jahe dan air.

\section{Peubah yang Diamati}

Peubah yang diamati terdiri dari nilai $\mathrm{pH}$ dan keempukan daging. Pengukuran nilai $\mathrm{pH}$ dilakukan sesuai rekomendasi Mach et al. (2008) Sebanyak $10 \mathrm{~g}$ daging sapi dihaluskan dan ditambah $40 \mathrm{ml}$ akuades selanjutnya diukur nilai $\mathrm{pH}$ daging tersebut menggunakan $\mathrm{pH}$ meter.

Keempukan daging diuji dengan cara mempersiapkan $70 \mathrm{~g}$ daging lalu direndam dalam larutan jahe (blend jahe ) sesuai dengan perlakuan yang sudah direncanakan (P0, P1, P2, dan P3). Uji keempukan daging diklakukan dengan alat penetrometer. Jarum yang terdapat pada [enetrometer ditusukkan pada permukaan potongan daging. Penetrometer menunjukkan angka tertentu yang memperlihatkan tingkat keempukan daging.

\section{HASIL DAN PEMBAHASAN}

\section{A. Pengaruh Perlakuan Terhadap Nilai pH}

Rata-rata $\mathrm{pH}$ pada masing-masing perlakuan terdapat pada Tabel 1. Hasil penelitian menunjukkan bahwa perlakuan lama perendaman daging sapi dalam blend jahe berpengaruh tidak nyata $(\mathrm{P}>0,05)$ terhadap $\mathrm{pH}$ daging sapi. Hal ini diduga disebabkan aktivitas enzim protease dalam daging sapi yang direndam dalam blend jahe selama 10 menit, 20 menit, dan 30 menit relatif sama. Enzim tersebut menghidrolisis protein muskulus penyusun struktur daging (aktin dan miosin) dan jaringan ikat yang terdiri dari kolagen, elastin, dan retikulin (Suantika et al. (2017).

Perlakuan lama perendaman daging sapi dalam blend jahe tidak berpengaruh terhadap nilai $\mathrm{pH}$ karena $\mathrm{pH}$ awal blend jahe pada konsentrasi $15 \% \quad(6,49)$ mendekati netral sehingga lama perendaman yang bervariasi tidak berpengaruh terhadap $\mathrm{pH}$ daging sapi. 
Tabel 1. Rata-rata nilai $\mathrm{pH}$ daging sapi dengan pada lama perendaman berbeda.

\begin{tabular}{ccccc}
\hline \multirow{2}{*}{ Ulangan } & \multicolumn{3}{c}{ Perlakuan } & P3 \\
\cline { 2 - 5 } & P0 & P1 & P2 & 5,883 \\
1 & 5,94 & 5,74 & 5,8 & 5,722 \\
2 & 5,94 & 5,78 & 5,778 & 5,719 \\
3 & 5,94 & 5,871 & 5,773 & 5,8 \\
4 & 5,94 & 5,838 & 5,684 & 5,828 \\
5 & 5,94 & 5,727 & 5,827 & $5,79 \pm 0,06$ \\
\hline Rata-rata & $5,94 \pm 0,11$ & $5,79 \pm 0,09$ & $5,77 \pm 0,07$ &
\end{tabular}

Keterangan :

$\mathrm{P0}$ :daging sapi tanpa perendaman dengan blend jahe;

$\mathrm{P} 1$ :daging sapi direndam dalam blend jahe selama 10 menit;

$\mathrm{P} 2$ : daging sapi direndam dalam blend jahe selama 20 menit;

P3: daging sapi direndam dalam blend jahe selama 30 menit.

Kisaran $\mathrm{pH}$ daging pada semua perlakuan berada di atas titik isoelektrrik sehingga terjadi peningkatan air dalam daging sapi. Hal ini sesuai dengan pendapat (Soeparno 2005) bahwa daya mengikat air menurun dari $\mathrm{pH}$ tinggi sampai pada $\mathrm{pH}$ titik isoelektrik protein-protein daging yang nilainya $5,0-5,1$. Protein daging pada $\mathrm{pH}$ isoelektrik tidak bermuatan (jumlah muatan positif sama dengan jumlah muatan negatif) dan solubilitasnya minimal. Sejumlah muatan positif dibebaskan pada saat nilai $\mathrm{pH}$ daging lebih tinggi daripada $\mathrm{pH}$ isoelekrik protein daging sehingga terjadi surplus muatan negatif. Hal tersebut mengakibatkan terjadinya penolakan dari miofilamen dan molekul air memiliki kesempatan lebih banyak untuk menempati ruangan. Demikian pula pada daging dengan $\mathrm{pH}$ lebih rendah dari titik isoelektrik protein daging. Pada kondisis tersebut juga terjadi penolakan miofilamen dan memberikan ruang pada molekul-molekul air, terdapat akses muatan positif yang mengakibatkan penolakan miofilamen dan memberi lebih banyak ruang untuk molekul-molekul air.
Pengaruh lain yang diduga menyebabkan tidak berpengaruhnya perlakuan terhadap nilai $\mathrm{pH}$ karena $\mathrm{pH}$ awal blend jahe dengan konsentrasi $15 \%(5,7-5,9)$ mendekati nilai $\mathrm{pH}$ larutan jahe normal (6.0--7.0). Hal tersebut mengakibatkan perlakuan lama perendaman daging sapi dalam blend jahe tidak berpengaruh terhadap $\mathrm{pH}$ daging sapi. Hal ini sesuai dengan Suantika et al. (2017) yang menyatakan bahwa perlakuan perendaman daging ke dalam sari jahe tidak berpengaruh terhadap $\mathrm{pH}$ daging. Sari jahe memiliki $\mathrm{pH}$ mendekati pH netral $(6,49)$.

\section{B. Pengaruh Perlakuan Terhadap Keempukan}

Hasil penelitian menunjukkan bahwa perlakuan perendaman daging sapi pada blend jahe dengan lama waktu penredaman yang berbeda berpengaruh nyata $(\mathrm{P}<0,05)$ terhadap keempukan daging sapi. Keempukan daging diukur pada posisi melintang (Tabel 2).

Tabel 2. Rata-rata nilai keempukan daging sapi dengan lama perendaman berbeda menggunakan blend jahe pengukuran melintang

\begin{tabular}{ccccc}
\hline \multirow{2}{*}{ Ulangan } & \multicolumn{3}{c}{ Perlakuan } \\
\cline { 2 - 5 } & P0 & P1 & P2 & P3 \\
\hline 1 & 2 & 2,8 & 2,7 & 2,9 \\
2 & 1,9 & 2,6 & 2,6 & 2,9 \\
3 & 1,9 & 2,5 & 2,7 & 2,8 \\
4 & 2 & 2,7 & 2,6 & 2,9 \\
5 & 1,9 & 2,6 & 2,7 & 3 \\
\hline Rata-rata & $1,94 \pm 0,05^{\mathrm{a}}$ & $2,64 \pm 0,11^{\mathrm{b}}$ & $2,66 \pm 0,5^{\mathrm{b}}$ & $2,9 \pm 0,5^{\mathrm{c}}$ \\
\hline
\end{tabular}

Keterangan :

$\mathrm{P} 0$ :daging sapi tanpa perendaman dengan blend jahe;

$\mathrm{P} 1$ :daging sapi direndam dalam blend jahe selama 10 menit;

P2: daging sapi direndam dalam blend jahes elama 20 menit;

P3: daging sapi direndam dalam blend jahe selama 30 menit;

*Superscript dengan huruf yang sama kearah baris bermakna tidak beda nyata $(\mathrm{P}>0,05)$ berdasarkan uji BNT. 
Hal tersebut berarti bahwa lama perendaman dalam blend jahe secara fisiologis memengaruhi tekstur dan keempukan daging. Kondisi tersebut diduga disebabkan oleh meningkatnya aktivitas enzim proteolitik dalam daging akibat perlakuan perendaman dalam blend jahe. Kemampuan enzim proteolitik dalam memecah ikatan antarserabut daging melalui proses hidrolisis mengakibatkan daging semakin empuk seiring dengan meningkatnya lama perendaman. Perbedaan keempukan yang dihasilkan diduga karena enzim proteolitik dalam daging sapi memerlukan waktu yang berbeda untuk menghidrolisis protein dengan petrbedaan lama perendaman. Daging sapi yang tidak mendapat perlakuan perendaman dalam blend jahe menunjukkan keempukan yang paling rendah karena enzim proteolitik bekerja tanpa didukung oleh perlakuan yang membantu meningkatkan kerja enzim proteolotik.

Hasil uji BNT menunjukkan bahwa keempukan daging yang direndam dalam blend jahe selama 10 menit dan 20 menit tidak berbeda nyata $(\mathrm{P}>0,05)$. Hal tersebut disebabkan oleh pendeknya rentang waktu perendaman selama 10 menit dan 20 menit sehingga aktivitas enzim dalam melakukan hidolisis belum memperlihatkan perbedaan.

Perbedaan keempukan daging pada kontrol (tanpa perendaman) dan perendaman selama 30 menit $(\mathrm{P}<0,05)$ disebabkan oleh perbedaan rentang waktu perendaman yang cukup tajam sehingga hasil kerja enzim protreolitik dapat terlihat pada perbedaan keempukan daging pada kontrol dan lama perendaman selama 30 menit. Hasil penelitian juga menunjukkan bahwa peningkatan lama perendaman semakin meningkatkan kerja enzim proteolitik dalam melakukan hidrolisis terhadap ikatan protein dalam jaringan daging.

Lama perendaman memberikan pengaruh siginifikan terhadap keempukan daging karena memberikan waktu yang lebih lama lagi bagi enzim proteolitik untuk bekerja. Hal ini sesuai dengan sistem kerja enzim yang dipengaruhi oleh konsentrasi enzim, suhu, $\mathrm{pH}$, inhibitor dan waktu. Waktu kontak atau reaksi antara enzim dan substrat menentukan efektivitas kerja enzim. Semakin lama waktu reaksi maka kerja enzim juga akan semakin optimum (Akhadiyah dan Santoso, 2011). Enzim proteolitik pada rimpang jahe dapat melunakkan daging sebelum dimasak. Lama perendaman daging pada larutan rimpang jahe berpengaruh terhadap keempukan pada daging (Muchtadi dan Sugiyono, 1992),
Hasil uji lanjut BNT menunjukkan bahwa nilai keempukan daging pada posisi membujur $(2,70 \mathrm{~mm} / 50 \mathrm{~g} / 10$ detik) pada perlakuan kontrol (tanpa perendaman) berbeda dengan daging yang menadapat perlakuan perendaman selama 10 menit $(2,12 \mathrm{~m} / 50 \mathrm{~g} / 10$ detik $)$. Hal ini disebabkan oleh tidak adanya perlakuan perendaman terhadap daging pada kelompok control. Keempukan hanya berasal dari daging tersebut sehingga nilai keempukan daging kelompok kontrol lebih rendah daripada kelompok daging yang mendapat perlakuan perendaman. Nilai keempukan daging yang mendapat perlakuan perendaman dalam blend jahe selama 30 menit ( 2,96 mm/50 g/10 detik) berbeda nyata $(\mathrm{P}<0,05)$ dengan keempukan daging kelompok kontrol. Hal tersebut diduga disebabkan sudah optimalnya kerja enzim proteolitik seiring dengan meningkatnya lama perendaman daging dalam blend jahe.enzim proteolitik telah bekerja secara optimal dalam menghidrolisis protein serat otot dan jaringan ikat daging sapi.

Keempukan daging pada perlakuan tanpa perendaman blend jahe, direndan dalam blend jahe selama 10 menit, 20 menit, dan 30 menit masing-masing berbeda nyata $(\mathrm{P}<0,05)$. Hal ini diduga kerja enzim proteolitik pada perendaman dalam blen jahe bekerja dengan kecepatan berbeda. Enzim proteolitik bekerja semakin maksimal seiring dengan meningkatnya lama perendaman daging dalam blend jahe sehingga keempukan pada perlakuan dan tanpa perlakuan berbeda nyata. Nilai keempukan daging yang mendapat perlakuan perendaman dalam blend jahe selama 30 menit $(2,96 \mathrm{~mm} / 50$ gram $/ 10$ detik) berbeda nyata $(\mathrm{P}<0,05)$ dengan keempukan daging kelompok tanpa perendaman. Perbedaan tingkat keempukan tersebut diduga disebabkan oleh perbedaan kerja enzim dalam menghidrolisis protein serat otot dan jaringan ikat daging sapi seiring dengan perbedaan lama perendaman.

Proses glikolisis anaerob menyebabkan terbentuknya asm laktat. Semakin banyak asam laktat yang terakumulasi maka protein semakin banyak terdenaturasi sehingga tidak mampu mengikat air. Semakin sedikit air bebas yang diikat oleh protein di dalam daging maka nilai keempukan daging semakin rendah. Keempukan daging sapi disebabkan oleh terjadinya perubahan protein daging setelah daging direndam menggunakan blend jahe. Blend jahe mengandung enzim proteolitik yang biasa disebut dengan enzim zingibain. Enzim protease telah bekerja aktif menghidrolisa protein muskulus penyusun struktur daging, yaitu aktin 
dan myosin serta jaringan ikat yang terdiri dari kolagen, elastin, dan retikulin. Teruraunya protein daging aktin dan miosin serta terpecahnya jaringan ikat kolagen, elastin, retikulin ini maka akan memberikan tekstur lunak pada daging (Suantika et al. (2017).

Perendaman daging dalam blend jahe selama 10 menit, 20 menit dan 30 menit mengoptimalkan kerja enzim proteolitik dalam menghidrolisis protein serat otot dan jaringan ikat daging. Hasil penelitian juga menunjukkan bahwa peningkatan lama perendaman meningkatkan kecepatan reaksi (hidrolisis jarigan ikat). Kecepatan tersebut akan berhentipada batas waktu tertentu yang ditandai dengan tidak terjadinya peningkatan jumlah jaringan ikat yang terhidrolisis walaupun waktu kerja enzim ditingkatkan.

Lama perendaman memberikan pengaruh yang siginifikan terhadap keempukan daging yaitu pada waktu enzim proteolitik telah bekerja. Hal ini sesuai dengan sistem kerja enzim yang dipengaruhi oleh konsentrasi enzim, suhu, $\mathrm{pH}$, inhibitor dan waktu. Waktu kontak atau reaksi antara enzim dan substrat menentukan efektivitas kerja enzim. Semakin lama waktu reaksi maka kerja enzim juga akan semakin optimum (Akhadiyah dan Santoso, 2011).

Jahe mengandung enzim protease yaitu zingibain yang dapat memecah ikatan peptida menjadi molekul-molekul protein yang lebih sederhana (asam amino) sehingga dapat melunakkan daging. Hasil pemecahan protein tersebut akan membentuk ikatan yang mengkaitkan dua molekul asam amino yang disebut dipeptida. Dipeptida mempunyai gugus $\mathrm{COOH}$ dan -NH2 yang akan membentuk oligopeptida seperti carnosine, balenine dan anserine yang memiliki kemampuan sebagai antioksidan yang dapat menghambat reaksi oksidatif. Enzim zingibain yang terdapat dalam jahe dapat menghidrolisa protein yang ditandai dengan berkurangnya pita protein mayor dan bertambahnya pita protein minor. Semakin tinggi konsentrasi larutan jahe, maka semakin banyak kandungan enzim zingibain sehingga kemampuan untuk menghidrolisa protein semakin tinggi (Kurniawan 2014).

\section{SIMPULAN DAN SARAN}

\section{A. Simpulan}

Berdasarkan hasil dari penelitian, maka dapat disimpulkan bahwa lamanya waktu perendaman (10, 20, dan 30 menit) dengan konsentrasi blend jahe $15 \%$ belum memberikan pengaruh yang nyata terhadap $\mathrm{pH}$ daging, tetapi berpengaruh terhadap keempukan daging sapi. Nilai keempukan daging tertinggi terdapat pada daging sapi yang mendapat perlakuan perendaman blend jahe selama 30 menit..

\section{B. Saran}

Berdasarkan hasil penelitian ini maka disarankan untuk dilakukannya penelitian lebih lanjut dengan meningkatkan konsentrasi blend jahe.

\section{DAFTAR PUSTAKA}

Aberle, E.D., J.C. Forrest, H.B. Hendrick, M.D. Judge dan R.A. Merkel. 2001. Principles of Meat Science. W.H. Freeman and Co., San Fransisco.

Afrila, A. dan B. Santoso. 2011. Water holding capacity (WHC), kadar protein, dan kadar air dendeng sapi pada berbagai konsentrasi ekstrak jahe (Zingiber officinale roscoe) dan lama perendaman yang berbeda. Jurnal Ilmu dan Teknologi Hasil Ternak. Vol. 6 (2): 4146.

Anna, P. dan F.M.T. Supriyanti. 2009. DasarDasar Biokimia. Universitas Indonesia Press, Jakarta. 155.

Apriyanto,. A. 1989. Analisis Pangan. IPB Press. Bogor

Foster, S. 2000. Your Food is Your Medicine. http://www..stevenfoster.com/education /mono graph/ginger.html. [15 April 2002].

Hapsari, D. 2000. Identifikasi dan kajian keamanan mikrobiologi produk-produk minuman sari jahe yang beredar di sekitar kota Bogor. Skripsi. Jurusan Teknologi Pangan dan Gizi, Fakultas Teknologi Pertanian, Institut Pertanian Bogor, Bogor.

Jenie, B. S. L., K. Undriyani, dan R. Dewanti. 1992. Pengaruh konsentrasi jahe dan waktu kontak terhadap aktivitas beberapa mikroba penyebab kerusakan pangan. Bul. Pen. Ilmu dan Tek. Pangan III (2): 1-16.

Kurniawan, R. F. 2014). Rahasia Terbaru Kedahsyatan Terapi Enzim. (I. Permatasari, Ed.). Healthy Books.

Lee, Y. B., D. J. Sehnert, \& C. R. Ashmore. 1986.Tenderization of meat with ginger rhizome protease. J. Food Sci. 51: 15581559.

Mach, N., A. Bach, A. Velarde, and M. Devant. 2008. Association between animal, transportation, slaughter house 
practices, and meat $\mathrm{pH}$ in beef. Meat Sci 78:232-238.

Nusa Bali. 2018. kekuatan vitamin b12. http://www.nusabali.com/berita/39419/k esehatan-kekuatan-vitamin-b12. $\quad[15$ Januari 2020].

PT. Haldin Pacific Semesta. 2001. Ginger. http://www.haldinnatural.com/techdata/ ginger. html. [15 April 2002].

Soeparno. 2005. Ilmu dan Teknologi Daging. Gadjah Mada University Press. Yogyakarta.

Suantika, R., L. Suryaningsih, dan J. Gumilar. 2017. Pengaruh lama perendaman dengan menggunakan sari jahe terhadap kualitas fisik (daya ikat air, keempukan dan $\mathrm{pH}$ ) daging domba. Universitas Padjadjaran. . Jurnal Ilmu ternak 17(2):67--72.

Thompson, E.H., Wolf, I.D. ANd Allen, C.E. 1973. Ginger rhizome : A new sourceof proteolityc enzym, J. Food Sci. 82 (2), 625-655

Thomas, P. R. 1984. Mempelajari pengaruh bubuk rempah-rempah terhadap pertumbuhan kapang Aspergillus flavus Link. Skripsi. Jurusan Teknologi Pangan dan Gizi, Fakultas Teknologi Pertanian, Institut Pertanian Bogor, Bogor. 